Ambiente \& Água - An Interdisciplinary Journal of Applied Science
ISSN 1980-993X - doi:10.4136/1980-993X
www.ambi-agua.net
E-mail: ambi.agua@gmail.com

\title{
Chironomus larvae (Chironomidae: Diptera) as water quality indicators along an environmental gradient in a neotropical urban stream
}

\author{
doi: 10.4136/ambi-agua.1533
}

Received: 30 Sep. 2014; Accepted: 27 Feb. 2015

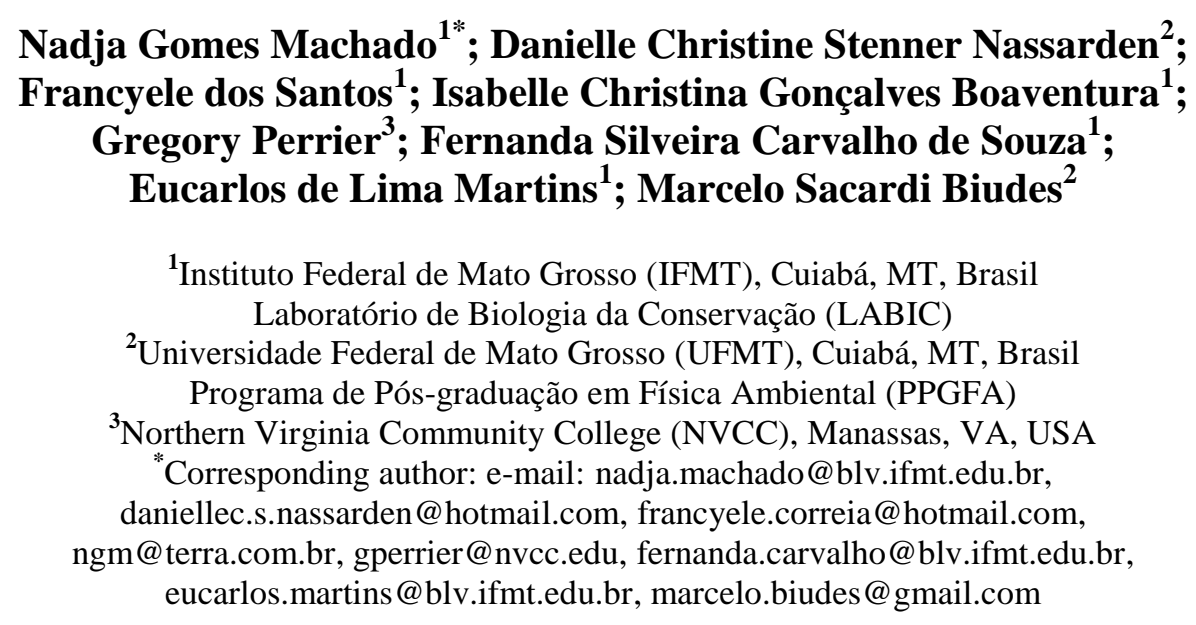

\begin{abstract}
Anthropogenic interference in urban lotic systems is a factor affecting the biota of waterbodies. Aquatic macro invertebrates are an important food source for fish and are valuable indicators of water quality. The objective of this work was to study Chironomus larvae (Chironomidae: Diptera) distribution along an environmental gradient in Barbado Stream, Cuiabá, MT, Brazil. No individual Chironomus was found in the springs of Barbado Stream, which may indicate preservation of the area. During the study period, we found 40.3 and 94.4 individuals $/ \mathrm{m}^{2}$ at points 3 and 4 (low course), respectively. There is eutrophication in these sites due to domestic sewage discharges, indicating low quality water. The Barbado Stream needs restoration projects that include an awareness of the residents of their neighborhood's environmental importance, and investments in the sanitation sector to prioritize the collection and treatment of wastewater and solid waste collection.
\end{abstract}

Keywords: aquatic macroinvertebrates, eutrophication lotic systems, water resources.

\section{Larvas de Chironomus (Chironomidae: Diptera) como indicador de qualidade da água ao longo de um gradiente ambiental em córrego urbano neotropical}

\section{RESUMO}

A interferência antrópica nos ambientes lóticos em áreas urbanas é um fator que afeta a biota dos corpos d'água. Macroinvertebrados aquáticos são importante fonte alimentar para peixes e são valiosos indicadores de qualidade da água. Nosso objetivo foi estudar a 
distribuição de larvas de Chironomus ao longo de um gradiente ambiental no Córrego do Barbado, Cuiabá, MT, Brasil. Nenhum indivíduo de Chironomus foi encontrado em suas nascentes, o que pode indicar preservação da área. Durante o período de estudo, nós encontramos 40,3 e 94,4 indivíduos $/ \mathrm{m}^{2}$ nos pontos 3 e 4 (baixo curso), respectivamente. Há eutrofização nestes locais devido descargas de esgoto in natura, indicando baixa qualidade da água. O córrego Barbado precisa de projetos de restauração que incluam a conscientização dos moradores dos bairros vizinhos sobre sua importância para o meio ambiente, e os investimentos no setor de saneamento para priorizar a coleta e tratamento de águas residuais e coleta de resíduos sólidos.

Palavras-chave: ambientes lóticos, eutrofização, macroinvertebrados aquáticos, recursos hídricos.

\section{INTRODUCTION}

Population growth causes an increase in consumption, space, and housing. Urban centers, which grow very quickly, are a great example, not taking into account the environmental pollution they cause. Aquatic ecosystems are one of the most affected by these changes (Braga et al., 2001). In recent decades, aquatic ecosystems have been altered to different degrees as a negative consequence of anthropogenic activities (e.g., mining, plumbing, dam construction, eutrophication, etc.). Rivers are impacted by everything that happens in the surrounding areas, to include land use and human occupation. Thus, the environmental characteristics of rivers, especially of their resident biological communities, provide information about the consequences of human action (Callisto et al., 2001).

The occupation of the river banks, considered as Permanent Preservation Areas (PPA) due to the expansion of urban areas, causes the removal of vegetative cover and soil sealing (Pellegrino et al., 2006). In addition, urban rivers and streams are subject to successive hydraulic engineering, drainage systems, altering their characteristics and transforming them into systems of underground drainage and wastewater receptacles (Galdino and Andrade, 2008). This occurs due to a lack of compliance with environmental criteria that seek the balance of the environment. Veyret (2001) argues that the notion of environment encompasses not only nature, much less merely fauna and flora alone, but also involves the interdependencies that exist among humans, societies and physical, chemical and biotic components, and also integrates its economic, social and cultural aspects.

Currently, at least a million people live in PPA areas in Brazil. Most of these are low-income people who have no legal access to affordable housing in urban areas with adequate infrastructure (Marandola and Hogan, 2005). As a result, the banks of rivers and streams and permanent preservation areas are occupied by low-income populations (unauthorized occupations) and also by middle-class condominiums. Coelho (2001) emphasizes that the upper class has large areas that allow vegetation and soil preservation, while the poorer class is concentrated in densely populated areas, which alters the carrying capacity of the soil.

Cuiabá, capital of Mato Grosso state, fits this scenario, due to rapid and unplanned urban growth. The Barbado Stream, one of the main tributaries of Cuiabá River which runs through Cuiabá, is environmentally degraded due to the sewage discharge of several homes and shopping areas (Bordest, 2003). Much of its stretch is already channeled, and another part doesn't have riparian vegetation, causing soil problems such as erosion, waterproofing, siltation, etc. (Colet and Soares, 2013; Ventura, 2011). It is degraded in the middle and lower courses, and the mouth while it is well preserved in the springs located in the State Park Massairo Okamura (Colet and Soares, 2013; Kreischer et al., 2012; Ventura, 2011).

Anthropogenic interference in lotic waters near urban areas can be an important factor affecting the biota of the river. These factors can impact aquatic fauna directly, through 
specific changes in habitats, or through temporary reduction in food availability and changes in other environmental variables (Callisto et al., 2001). There are several ways to assess water quality in waterbodies such as methods that focus on physical and chemical properties (i.e. dissolved oxygen, mercury, and water clarity), and biological measures (i.e. species as biological indicators) (Kenney et al., 2009). Biological indicators are based on the premise that biotic communities respond to changes in habitat and water quality resulting from anthropogenic disturbance (Karr, 1999; Machado et al., 2011).

In order to assess water quality on the basis of ecosystem health, it is best to study the response of the entire aquatic community to stress (Metcalfe, 1989). As this is obviously impractical, most studies have focused on a particular sector of the ecosystem, such as periphyton, plankton, macrobenthos or fish. While fish and algal assemblages have particular advantages in bioassessments (Barbour et al., 1999), macroinvertebrates provide a more localized assessment of their response to stream conditions due to the simple equipment used to collect them, and their lower mobility than fish (Kenney et al., 2009).

Macroinvertebrates, an important food source for fish, are valuable indicators of environmental degradation, as well as influence on nutrient cycling, primary productivity and decomposition (Wallace and Webster, 1996). These organisms inhabit the bottom substrate (sediment, debris, logs, macrophytes, filamentous algae, etc.) of freshwater habitat in at least one phase of their life cycle (Loyola, 1994). Some of them survive in extreme environments, and are able to live in a total absence of oxygen. Substrates directly influence their existence, and may thus be used as bioindicators (Melo and Froelich, 2001).

Among the groups of macroinvertebrates, the chironomid group is widely found in an environment impacted by sewage (Fagundes and Shimizu, 1997). This group belongs to the order Diptera, which can be found in all parts of the world, because they are considered extremely resistant; they are able to live in a complete absence of oxygen for several hours, and are considered scavengers, eating only organic matter (Pinder, 1986; Callisto and Esteves, 1995). Chironomid larvae are opportunistically omnivorous, ingesting a wide variety of food items (Cummins and Klug, 1979). In general, these larvae ingest five kinds of food: algae, detritus and associated microorganisms, macrophytes, wood debris, and invertebrates (Berg, 1995).

Considering the environmental gradient from the springs to the mouth of Barbado Stream, our objective was to study Chironomus larvae distribution as indicators of water quality in a neotropical urban stream.

\section{MATERIAL AND METHODS}

\subsection{Study area}

The basin of Barbado Stream is located in an urban area in the central-eastern portion of Cuiabá, Mato Grosso State (Brazil), and it flows to Cuiabá River (Figure 1).

The land cover is different throughout the course of the stream. In spring and upper course, there is Cerrado vegetation; in mouth, medium and lower courses, there is virtually no vegetation, because it was removed by human occupancy (Kondo et al., 2010). Points 1 and 2 were located in the springs (preserved areas located at Parque Estadual Massairo Okamura) and points 3 and 4 were located on the lower course (disturbed areas) (Colet and Soares, 2013; Kreischer et al., 2012; Ventura, 2011). According to the Köppen classification, the regional climate is Aw, which represents a hot and wet climate with rainfall in the summer and drought in the winter (Machado et al., 2014). The annual average air temperature ranges from 24 to $26^{\circ} \mathrm{C}$, with two distinct seasons, dry (autumn-winter) and wet (spring-summer); annual rainfall ranges from 1250 to $1500 \mathrm{~mm}$ (Maitelli, 1994). 


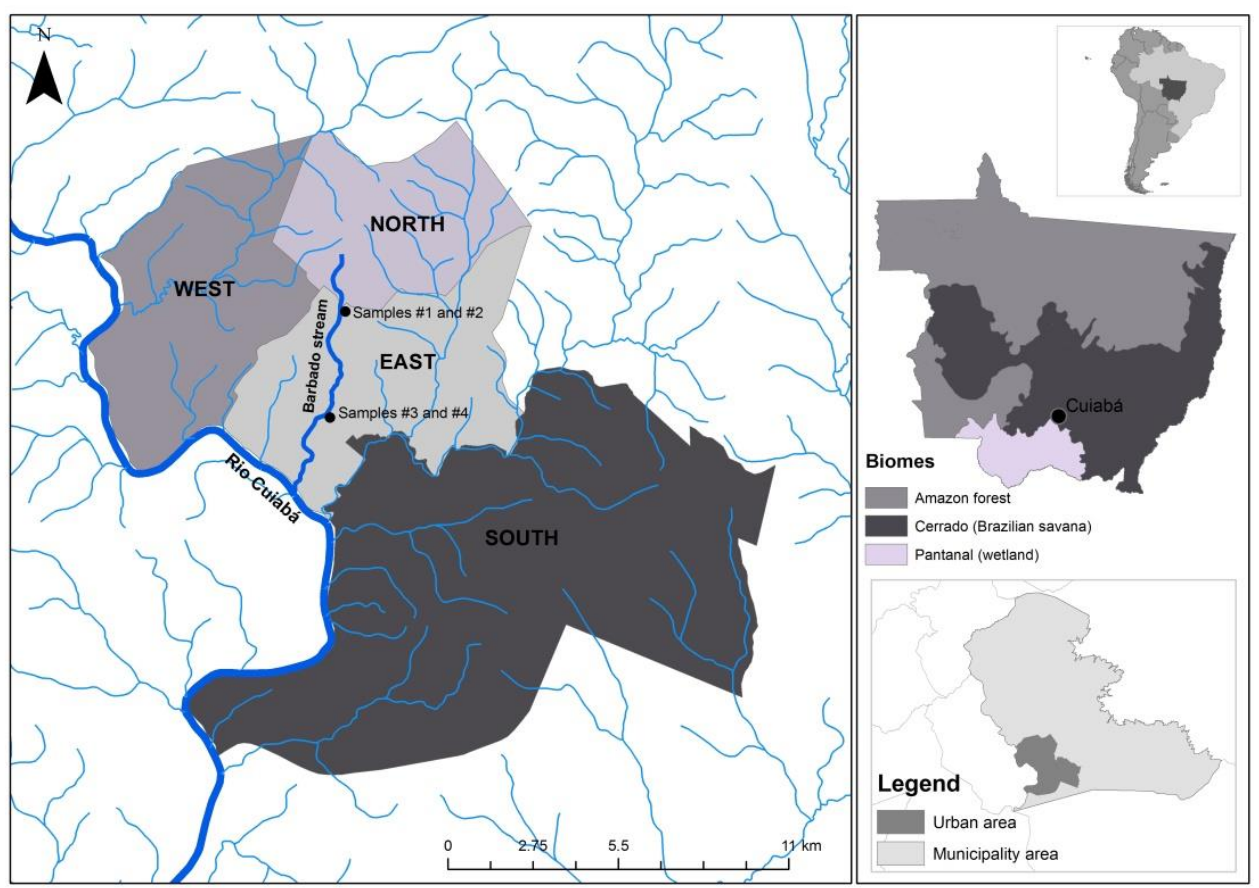

Figure 1. Location of sampled points at Barbado Stream in Cuiabá, Mato Grosso State, Brazil.

\subsection{Data collection}

Aquatic macroinvertebrates were sampled in 04 sites (Table 1) by Surber Sampler (mesh $200 \mathrm{~mm}$ and sample area of $30 \mathrm{~cm}$ x $30 \mathrm{~cm}$ ). The collected material was upturned, washed and placed into plastic bags containing 70\% alcohol. The material was sorted and identified to the lowest possible taxonomic level. Samples were collected in the even months from 2010 to 2012, totaling 15 samples. We measured width and depth using graduated tape along the stream channel. The substrate composition in each site was determined from surveys with a stick in equidistant points along the stream channel, as information on the channel depth was gathered. The overall substrate composition of each stream was characterized by the frequency of occurrence $(\%)$ of each type of substrate per site. The substrate type was classified into the following categories: root, trunk, leaves, sand, clay, silt, rock, slime, and plastic. Rainfall data were obtained from Instituto Nacional de Meteorologia (INMET).

Table 1. Sampling points in the Stream Barbados in Cuiabá, Mato Grosso State.

\begin{tabular}{lll}
\hline Site & Points & \multicolumn{1}{c}{ Stretch } \\
\hline 1P & Pool & Parque Estadual Massairo Okamura \\
1R & Riffle & Parque Estadual Massairo Okamura \\
2P & Pool & Parque Estadual Massairo Okamura \\
2R & Riffle & Parque Estadual Massairo Okamura \\
3P & Pool & Bairro Jardim das Américas \\
4R & Riffle & Universidade Federal de Mato Grosso (UFMT) \\
\hline
\end{tabular}




\section{RESULTS AND DISCUSSION}

The annual rainfall was $1596.50 \mathrm{~mm}$ in $2010,1673.00 \mathrm{~mm}$ in 2011 , and $1599.87 \mathrm{~mm}$ in 2012. The driest months were from May to September, and the wettest months were from January to March (Figure 2). The distribution of monthly rainfall from 2010 to 2012 showed a pattern similar to the normal climate of 1961-1990 for Cuiabá, with a wet season from October to March and dry season from April to September. The annual mean of accumulated precipitation $(1623.12 \mathrm{~mm})$ was higher than the annual average ranging from 1250 to $1500 \mathrm{~mm}$ (Maitelli, 1994).

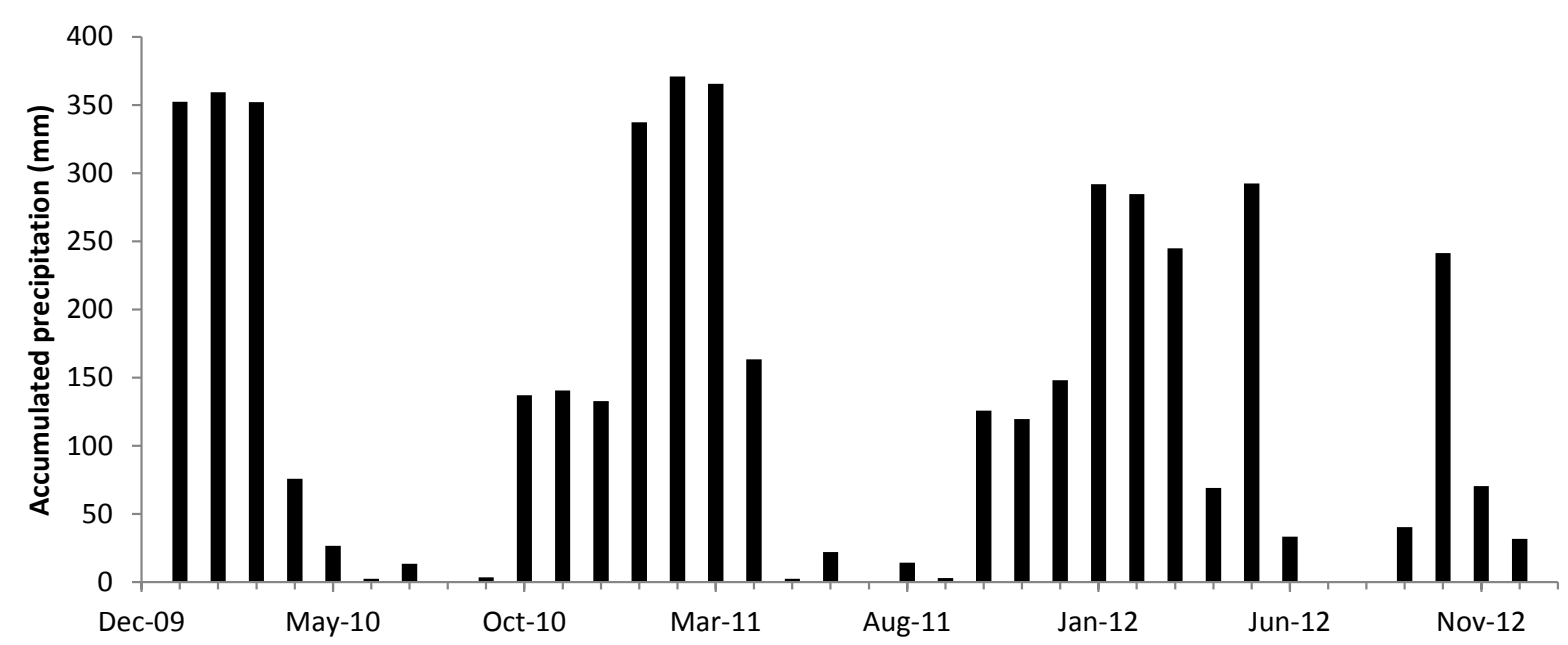

Figure 2. Average monthly rainfall from 2010 to 2012 in Cuiabá, Mato Grosso State.

Points 1P (pool), 1R (rifle), 2P (pool) and 2R (rifle) were mainly composed of rocks, leaves, and roots (Figure 3). On the other hand, points 3P and 4R were composed of sand and stone. However, plastic and slime were found only in points $3 \mathrm{P}$ and $4 \mathrm{R}$, indicating environmental degradation.

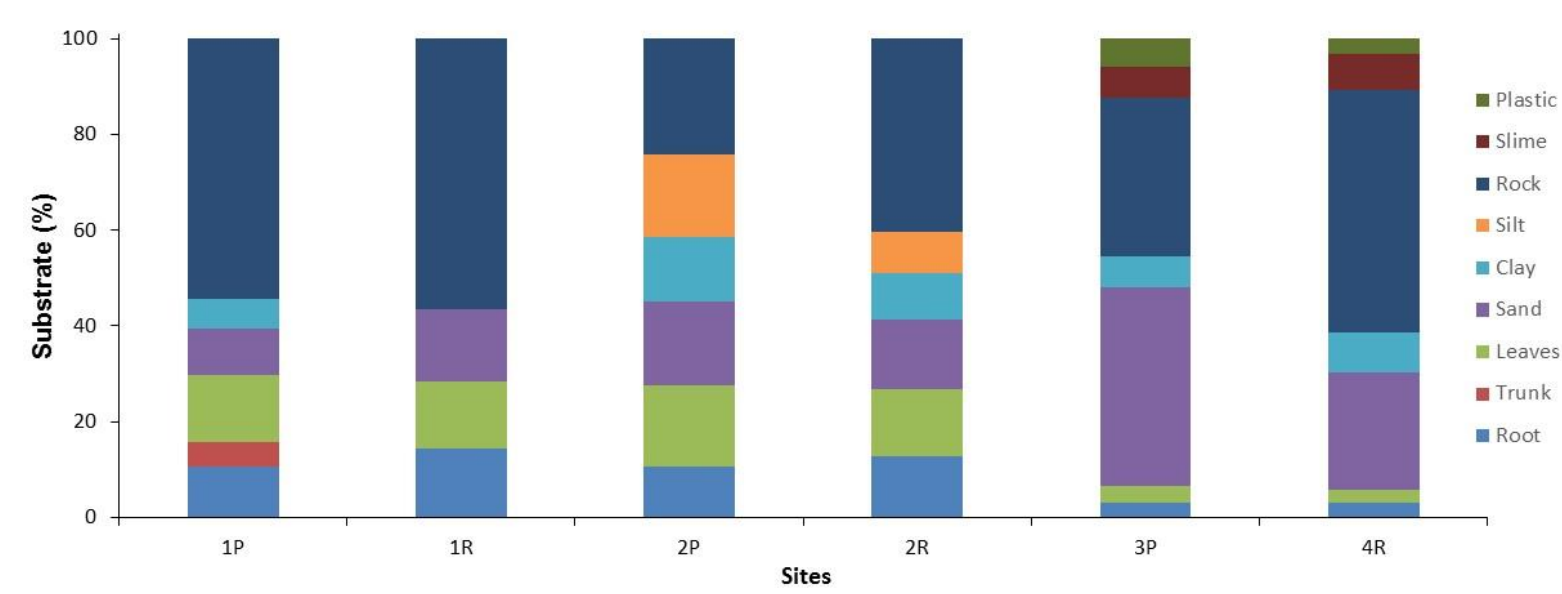

Figure 3. Characterization of substrate at Barbado stream in Cuiabá, Mato Grosso State, Brazil.

Chironomus (Chironomidae: Diptera) was only found at Barbado Stream. None was found at points 1P, 1R, 2P and 2R (Figure 4), which may indicate that this area is preserved. We found 40.3 and 94.4 individuals $/ \mathrm{m}^{2}$ at points $3 \mathrm{P}$ and $4 \mathrm{R}$ (low course), respectively. No Chironomus was found at points 3P and 4R in October and December of 2011 and 2012. 
Oliveira et al. (2010) confirmed Chironomus as indicators of organic pollution. They found Chironomus mean density varying from 23999.69 to 30253.96 individuals $/ \mathrm{m}^{2}$ in polluted sites while 24.13 individuals $/ \mathrm{m}^{2}$ in the best water quality site. According to Sibley et al (1997), the numerical abundance of this genus is greatly influenced by food availability independently of the size of the substrate particles. The genus Chironomus is tolerant to organic and industrial pollutants, which means its occurrence and dominance are an effective biological indicator of stream pollution (Oliveira et al., 2010).

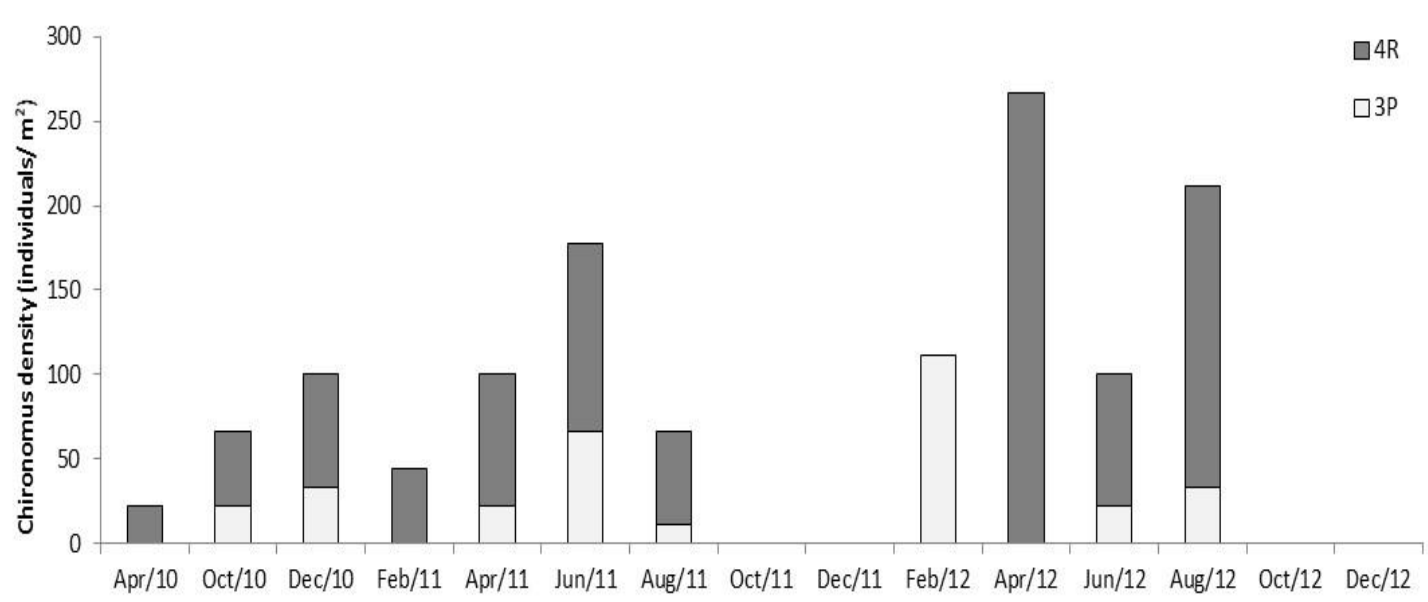

Figure 4. Mean density of Chironomus larvae (individuals $/ \mathrm{m}^{2}$ ) in sampled points at Barbado Stream in Cuiabá, Mato Grosso State.

The aquatic macroinvertebrates include representatives of crustaceans, gastropods, bivalves, oligochaetes and many insect orders (Allan, 1995; Merritt et al., 2008; Thorp and Covich, 2001). However, insects are often the dominant group of freshwater benthic macroinvertebrates in both absolute numbers and species diversity, which is not surprising given that the juvenile stages of many terrestrial insects are typically aquatic (Merritt et al., 2008). The benthic macroinvertebrate community of freshwater organisms is more than $0.5 \mathrm{~mm}$ in size, and is therefore visible to the naked eye (Pérez, 1996).

Chironomus Meigen (1803) is a genus of non-biting midges in the subfamily Chironominae (Chironomidae: Diptera). According to Simpson and Bode (1980), this genus is ecologically versatile, with various species living in standing or flowing waters as well as in polluted or clean waters. Chironomus is commonly associated with the presence of decomposing organic matter and aquatic macrophytes (Sanseverino and Nessimian, 2001). Resende and Takeda (2007) and Fusari (2006) recorded the genus in areas strongly impacted by anthropogenic actions. The increase in the density of larvae of the Chironomus in environments with eutrophic features has been registered in several types of ecosystems (Frank, 1963; Learner and Edwards, 1966; Devái, 1990; Tate and Heiny, 1995; Botts, 1997).

They contribute to many important ecological functions, such as decomposition and nutrient cycling, and also serve an important role in aquatic food webs as both consumers and prey (Covich et al., 1999; Moore, 2006; Vanni, 2002; Wallace and Webster, 1996). Thus, they play an important role in nutrient dynamics, transforming organic matter into energy (Callisto et al., 2001). Dead organic matter, i.e., the proportion of substrates, is the main pathway in most carbon ecosystems (Wallace et al., 1997).

Habitat quality is one of the most important factors in the success of colonization and the establishment of biological communities in lentic and lotic environments (Marques et al., 1999). Rolling sediment and fragmentation of litter from riparian vegetation are examples of processes under the responsibility of the benthic community, resulting in the release of 
nutrients to the water and aeration of the sediments (Cummins et al, 1989; Devái, 1990). The health and the quality of a waterbody depend on these processes (Marques et al., 1999).

Substrates as physically complex as leaves, wood, weeds and mosses generally have greater biodiversity than simpler substrates such as sand and rock bed (Vinson and Hawkins, 1998). Compared with other substrates, the accumulations of litter in streams of forested areas appear to be preferentially occupied by chironomid larvae (Sanseverino and Nessimian, 2001). Accumulations of litter release energy, matter and nutrients into the water. The benthic macroinvertebrate community can have its structure strongly influenced by substrate composition and micro habitats within riverbeds. In this perspective, each type of substrate supports a particular community of macroinvertebrates, which are not randomly distributed (Melo and Froelich, 2001).

Chironomid larvae are usually found where there is organic matter, an almost total absence of oxygen, and in many lentic and lotic environments. Climatic factors also influence the amount of Chironomidae larval found. Tropical regions are considered favorable for the growth of the larvae, which usually takes around 15 days, ranging from a temperature from $0^{\circ}$ to $32^{\circ} \mathrm{C}$ (Callisto et al., 2001). With the enabling factors it can be predicted that a high number of generations occur each year.

Kreischer et al. (2012) observed that the values of dissolved oxygen and conductivity indicate dumping of domestic sewage into points located on the lower course of Barbado Stream. Colet and Soares (2013) showed low environmental quality at the top, middle and lower courses and at the mouth of Barbado Stream, while the springs showed better quality. The monitoring of water quality of the sub-basins of the Cuiabá River revealed increased turbidity, a decrease in dissolved oxygen and a high amount of total coliforms and Escherichia coli in Barbado downstream, due to the implementation of sanitary sewers (Mato Grosso, 2006). Oliveira and Silva (2013) showed the presence of iron and lead in the water of Barbado Stream the sources of which include improper disposal of untreated sewage, solid waste and urban runoff, which makes the water unfit for public supply without prior treatment, and which may compromise the aquatic flora and fauna of the stream basin.

The CONAMA resolution 357/2005 (CONAMA, 2005) establishes that uncategorized rivers must comply with the limits for water bodies of type 2 waters which are those for: (a) supply for human consumption, after conventional treatment; (b) protection of aquatic communities; (c) primary contact recreation such as swimming, water skiing and scuba diving; (d) Irrigation of vegetables, fruit trees and parks, gardens, sports fields and leisure, with which the public may come into direct contact; and (e) aquaculture and fishing activity. Therefore, most of the Barbado Stream (high, medium and low courses and mouth) does not fit the water type 2 established by the CONAMA resolution.

The quality of surface waters is a very sensitive issue because anthropogenic actions degrade surface waters and impair their use for drinking, industrial, agricultural, recreation or other purposes (Carpenter et al., 1998; Jarvie and Neal, 1998). The concern that fresh water will be a scarce resource in the future (Pesce and Wunderlin, 2000) has forced countries into the evaluation of river water qualities in recent years (Kannel et al., 2007). A comprehensive river water quality monitoring program is becoming a necessity in order to safeguard public health and to protect the valuable fresh water resources (Kannel et al., 2007).

In this context, macroinvertebrate community composition changes along a gradient of stream habitat and water quality (Resh et al., 1995), and stream health can be assessed in relation to reference conditions (Barbour and Gerritsen, 2006). Thus, the use of benthic macroinvertebrate indicators greatly enhances states' ability to identify and subsequently improve impaired water (Kenney et al., 2009). 


\section{CONCLUSION}

The Chironomus larvae was the only recorded group of macroinvertebrates at Barbado Stream during the study period, probably due to the presence of organic matter from sewage in its downstream course, indicating eutrophication. Chironomus larvae can be used as an indicator of water quality, because they mostly appear in sites where there is sewage input. The Barbado Stream needs restoration projects which include an awareness on the part of the residents of their neighborhood's environmental importance, and investment in the sanitation sector to prioritize the collection and treatment of wastewater and solid waste collection, avoiding sewage discharge.

\section{ACKNOWLEDGEMENTS}

We are grateful to Instituto Federal de Mato Grosso (IFMT) for financial and logistical support.

\section{REFERENCES}

ALLAN, J. D. Stream ecology: structure and function of running waters. Boston: Chapman \& Hall, 1995. 388p.

BARBOUR, M. T.; GERRITSEN, J. Key features of bioassessment development in the United States of America , pp. 351 - 366. In: ZIGLIO, E.; SILIGARDI, M.; FLAIM, G. (Eds). Biological Monitoring of Rivers. West Sussex: John Wiley \& Sons, 2006. 469p.

BARBOUR, M. T.; GERRITSEN, J.; SNYDER, B. D.; STRIBLING, J. B. Rapid bioassessment protocols for use in streams and wadeable rivers: periphyton, benthic macroinvertebrates and fish. 2nd Edition. Washington, DC: USEPA, 1999. 339 p.

BERG, H. B. Larval food and feeding behavior. In: ARMITAGE, P. D.; CRANSTON, P. S.; PINDER, L. C. V. (Eds.). The Chironomidae: biology and ecology of non-biting midges. London: Chapman \& Hall, 1995. 584p.

BORDEST, S. M. L. A bacia do Córrego do Barbado, Cuiabá, Mato Grosso. Cuiabá: Gráfica Print, 2003. 116 p.

BOTTS, P. S. Spatial pattern, patch dynamics and successional change: chironomid assemblages in a Lake Erie coastal wetland. Freshwater Biology, v. 37, p. 277-286, 1997. http://dx.doi.org/10.1046/j.1365-2427.1997.00145.x

BRAGA, B.; PORTO, M.; TUCCI, C.; MORELLI, E. Monitoramento de Quantidade e Qualidade das Águas In: REBOUÇAS, A. C.; BRAGA, B.; TUNDISI, J. G. (org.). Águas doces no Brasil: capital e ecológico, uso e conservação: 2. ed., rev. ampl. São Paulo: Escrituras, 2001.

CALLISTO, M. F. P.; ESTEVES, F. A. Distribuição da comunidade de macroinvertebrados bentônicos em um ecossistema amazônico impactado por rejeito de Bauxita - Lago Batata (Pará, Brasil). Oecologia Brasiliensis, p. 335-348, 1995.

CALLISTO, M.; MORETTI, M.; GOULART, M. D. C. Macroinvertebrados bentônicos como ferramenta para avaliar a saúde de riachos. Revista Brasileira de Recursos Hídricos, v. 6, n. 1, p. 71-82, 2001. 
CARPENTER, S. R.; CARACO, N. F.; CORRELL, D. L.; HOWARTH, R. W.; SHARPLEY, A. N.; SMITH, V. H. Nonpoint pollution of surface waters with phosphorus and nitrogen. Ecological Applications, v. 8, n. 3, p. 559-568, 1998.

http://dx.doi.org/10.1890/1051-0761(1998)008[0559:NPOSWW]2.0.CO;2

COELHO, M. C. N. Impactos ambientais em áreas urbanas - teorias, conceitos e métodos de pesquisa. In: GUERRA, A. J. T.; CUNHA, S. B. (Orgs.). Impactos ambientais urbanos no Brasil. Rio de Janeiro: Bertrand Brasil. 2001. p. 19-45.

COLET, K. M.; SOARES, A. K. Diagnóstico e índices de qualidade ambiental da bacia do Córrego do Barbado, Cuiabá-MT. Engenharia Ambiental, v. 10, n. 2, p. 22-40, 2013.

CONSELHO NACIONAL DE MEIO AMBIENTE (Brasil). Resolução CONAMA n 357, de 17 de Março de 2005. Disponível em:

http://www.mma.gov.br/port/conama/res/res05/res35705.pdf. Access in: 28 Feb. 2015.

COVICH, A. P.; PALMER, M. A.; CROWL, T. A. The role of benthic invertebrate species in freshwater ecosystems: Zoobenthic species influence energy flows and nutrient cycling. BioScience, v. 49, p. 119-127, 1999. http://dx.doi.org/10.2307/1313537

CUMMINS, K. W.; WILZBACH, M. A.; GATES, D. M.; PERRY, J. B.; TALIAFERRO, W. B. Shredders and riparian vegetation. Bioscience, v. 39, n. 1, p. 24-30, 1989. http://www.jstor.org/stable/1310804

CUMMINS, K. W.; KLUG, M. J. Feeding ecology on stream invertebrates. Annual Review of Ecology, Evolution, and Systematics, v. 10, p. 147-172, 1979. http://www.jstor.org/stable/2096788

DEVÁI, G. Ecological background and importance of the change of chironomid fauna in shallow Lake Balaton. Hidrobiologia, v. 191, p. 189-198, 1990. http://dx.doi.org/10.1007/BF00026052

FAGUNDES, R. C.; SHIMIZU, G. Y. Avaliação da qualidade da água do Rio Sorocaba-SP, através da comunidade bentônica. Revista Brasileira de Ecologia, v. 1, p. 63-66, 1997.

FRANK, C. Ecology, production and anaerobic metabolism of Chironomus plumosus L. larvae in a shallow lake. II Anaerobic metabolism. Archiv für Hydrobiologie, v. 96, n. 3, p. 354-362, 1963.

FUSARI, L. M. Estudos das comunidades de macroinvertebrados bentônicos das Represas do Monjolinho e do Fazzari no campus da UFSCar, município de São Carlos, SP. 2006. 80 f. Dissertação (Mestrado) - Universidade Federal de São Carlos, São Carlos, 2006.

GALDINO, Y. S. N.; ANDRADE, L. M. Z. Interações entre a Cidade e Paisagem ao longo da Sub-Bacia do Barbado, Cuiabá - MT. In: ENCONTRO NACIONAL DA ANPPAS, 4. 2008, Brasília. Anais... Brasília: ANPPAS, 2008. 19p.

JARVIE, H. P.; WHITTON, B. A.; NEAL, C. Nitrogen and phosphorus in east coast British rivers: speciation, sources and biological significance. Science of the Total Environment, v. 210-211, p. 79-109, 1998. http://dx.doi.org/10.1016/S00489697(98)00109-0 
KANNEL, P. R.; LEE, S.; LEE, Y-S.; KANEL, S. R.; KHAN, S. P. Application of Water Quality Indices and Dissolved Oxygen as Indicators for River Water Classification and Urban Impact Assessment. Environmental Monitoring and Assessment, v. 132, p. 93110, 2007. http://dx.doi.org/10.1007/s10661-006-9505-1

KARR, J. R. Defining and measuring river health. Freshwater Biology, v. 41, p. 221-234, 1999. http://dx.doi.org/10.1046/j.1365-2427.1999.00427.x

KENNEY, M. A.; SUTTON-GRIER, A. E.; SMITH, R. F.; GRESENS, S. E. Benthic macroinvertebrates as indicators of water quality: The intersection of science and policy. Terrestrial Arthropod Reviews, v. 2, p. 99-128, 2009.

KONDO, D. B.; OLIVEIRA, E. C. G.; ROCHA, L. A.; OLIVEIRA, M. R. A. Bacia do córrego Barbado. In: OLIVEIRA, M. R. A. Caminhando pelo Barbado: o córrego e sua gente. Cuiabá: Print, 2010. 60p.

KREISCHER, T. C. V.; GONÇALVES, D. M. M.; VALENTINI, C. M. A. Aspectos hidroambientais do Córrego Barbado em Cuiabá-MT. Holos, v. 28, n. 1, p. 86-109, 2012. http://dx.doi.org/10.15628/holos.2012.697

LEARNER, M. A.; EDWARDS, R. W. The distribution of the midge Chironomus riparius in a polluted river system and its environs. International Journal of Air and Water Pollution, v. 10, p. 757-768, 1966.

LOYOLA, R. G. N. Contribuição ao Estudo dos Macroinvertebrados Bentônicos em Afluentes da Margem Esquerda do Reservatório de Itaipu. 1994. 300f.Tese (Doutorado em Zoologia) - Universidade Federal do Paraná, Curitiba, 1994.

MACHADO, N. G.; SILVA, F. C. P.; BIUDES, M. S. Efeito das condições meteorológicas sobre o risco de incêndio e o número de queimadas urbanas e focos de calor em CuiabáMT, Brasil. Ciência e Natura, v. 36, n. 3, p. 459-469, 2014. http://dx.doi.org/10.5902/2179460X11892

MACHADO, N. G.; VENTICINQUE, E. M.; PENHA, J. Effect of environmental quality and mesohabitat structure on a Biotic Integrity Index based on fish assemblages of cerrado streams from Rio Cuiabá basin, Brazil. Brazilian Journal of Biology, v. 71, n. 3, p. 577-586, 2011. http://dx.doi.org/10.1590/S1519-69842011000400002

MAITELLI, G. T. Uma abordagem tridimensional de clima urbano em área tropical continental. O exemplo de Cuiabá - MT. 1994. Tese (Doutorado em Geografia) Universidade de São Paulo, São Paulo, 1994.

MARANDOLA, E.; HOGAN, D. J. Vulnerabilidade e riscos: entre geografia e demografia. Revista Brasileira de Estudos de População, v. 22, n. 1, p. 29-53, 2005.

MARQUES, M. G. S. M.; FERREIRA, R. L.; BARBOSA, F. A. R. A comunidade de macroinvertebrados aquáticos e características limnológicas das lagoas Carioca e da Barra, Parque Estadual do Rio Doce, MG. Revista Brasileira de Biologia, v. 59, n. 2, p. 203-210, 1999. http://dx.doi.org/10.1590/S0034-71081999000200004

MATO GROSSO. Secretaria de Estado de Meio Ambiente - SEMA. Superintendência de Recursos Hídricos - SURH. Relatório de monitoramento da qualidade das águas da sub-bacia do Rio Cuiabá - MT, 2005. Elaborado por Adélia Alves Araújo et. al. Cuiabá: SEMA; SURH, 2006. 55p. 
MELO, A. S.; FROEHLICH, C. G. Macroinvertebrates in neotropical streams: richness patterns along a catchment and structure between 2 seasons. Journal of North American Benthological Society, v. 20, p. 1-16, 2001. http://dx.doi.org/10.2307/1468184

MERRITT, R. W.; CUMMINS, K. W.; BERG, M. B. An introduction to the aquatic insects of North America. 4th Edition. Dubuque: Kendall Hunt Publishing, 2008. 1158 p.

METCALFE, J. L. Biological water quality assessment of running waters based on macroinvertebrate communities: History and present status in Europe. Environmental Pollution, v. 60, n. 1-2, p. 101-139, 1989. http://dx.doi.org/10.1016/0269-7491(89)90223-6

MOORE, J. W. Animal ecosystem engineers in streams. Bioscience, v. 56, p. 237-246, 2006. http://dx.doi.org/10.1641/0006-3568(2006)056[0237:AEEIS]2.0.CO;2

OLIVEIRA, A.; SILVA, N. Determinação da concentração de metais em águas do Córrego do Barbado, Cuiabá - MT. Revista Gestão e Sustabilidade Ambiental, v. 2, n. 1, p. 47-63, 2013.

OLIVEIRA, V.; MARTINS, R.; ALVES, R. Evaluation of water quality of an urban stream in southeastern Brazil using Chironomidae Larvae (Insecta: Diptera). Neotropical Entomology, v. 39, n. 6, p.873-878, 2010. http://dx.doi.org/10.1590/S1519566X2010000600004

PELleGrinO, P. R. M.; GUEDES, P. P.; PIRILlO, F. C.; FERNANDES, S. A. A. A paisagem de borda: uma estratégia para a condução da biodiversidade e das pessoas. In: COSTA, L. M. S. A. (Org.). Rios e paisagem urbana em cidades brasileiras. Rio de Janeiro: Viana \& Mosley, 2006. p. 57-76.

PÉREZ, G. R. Guía para el estudio de los macroinvertebrados acuáticos del Departamento de Antioquia. Medellín: Universidad de Antioquia, 1996. 217 p.

PESCE, S. F.; WUNDERLIN, D. A. Use of water quality indices to verify the impact of Cordoba city (Argentina) on Suquýa river. Water Research, v. 34, n. 11, p. 2915-2926, 2000 .

PINDER, L. C. V. Biology of freshwater Chironomidae. Annual Review of Entomology, v. 31, p. 1-23, 1986. http://dx.doi.org/10.1146/annurev.en.31.010186.000245

RESENDE, D. L. M. C.; TAKEDA, A. M. Larvas de Chironomidae (Diptera) em três Reservatórios do Estado do Paraná, Brasil. Revista Brasileira de Zoociências, v. 9, n. 2, p. 167-176, 2007.

RESH, V. H.; NORRIS, R. H.; BARBOUR, M. T. Design and implementation of rapid assessment approaches for water-resource monitoring using benthic macroinvertebrates. Australian Journal of Ecology, v. 20, p. 108-121, 1995. http://dx.doi.org/10.1111/j.1442-9993.1995.tb00525.x

SANSEVERINO, A. M.; NESSIMIAN, J. L. Hábitats de larvas de Chironomidae (Insecta, Diptera) em riachos de Mata Atlântica no Estado do Rio de Janeiro. Acta Limnologica Brasiliensia, v. 13, n. 1, p. 29-38, 2001. 
SIBLEY, P. K.; BENOIT, D. A.; ANKLEY, G. T. Life cycle and behavioural assessments of the influence of substrate particle size on Chironomus tentas (Diptera: Chironomidae) in laboratory assays. Hydrobiologia, v. 361, p. 1-9, 1997.

http://dx.doi.org/10.1023/A:1003159323259

SIMPSON, K. W.; BODE, R. W. Common larvae of Chironomidae (Diptera) from New York state streams and rivers with particular reference to the fauna of artificial substrates. New York: State Museum and Science Service, 1980. 105 p. (Bulletin, n. 439)

TATE, C. M.; HEINY, S. J. The ordination of benthic invertebrate communities in the South Platte Basin in relation to environmental factors. Freshwater Biology, v. 33, p. 439454, 1995. http://dx.doi.org/10.1111/j.1365-2427.1995.tb00405.x

THORP, J. H.; COVICH, A. P. Ecology and classification of North American freshwater invertebrates. 2nd Edition. San Diego: Academic Press, 2001.

VANNI, M. J. Nutrient cycling by animals in freshwater ecosystems. Annual Review of Ecology and Systematics, v. 33, p. 341-370, 2002. http://dx.doi.org/10.1146/annurev.ecolsys.33.010802.150519

VENTURA, R. M. G. Caracterização ambiental e hidrológica da Bacia do Córrego do Barbado em Cuiabá-MT. 2011. 112f. Dissertação (Mestrado em Engenharia de Edificações e Ambiental) - Universidade Federal do Mato Grosso, Cuiabá, 2011.

VEYRET, Y. Os riscos: o homem como agressor e vítima do meio ambiente. São Paulo: Contexto, 2001. 320p.

VINSON, M. R.; HAWKINS, C. P. Biodiversity of stream insects: variation at local, basin and regional scales. Annual Review of Entomology, v. 43, p. 271-93, 1998. http://dx.doi.org/10.1146/annurev.ento.43.1.271

WALLACE, J. B.; EGGERT, S.L.; MEYER, J. L.; WEBSTER, J. R. Multiple trophic levels of a forest stream linked to terrestrial litter inputs. Science, v. 277, p. 102-104, 1997. http://dx.doi.org/10.1126/science.277.5322.102

WALLACE, J. B.; WEBSTER, J. R. The role of macroinvertebrates in stream ecosystem function. Annual Review of Entomology, v. 41, p. 115-139, 1996. 